\title{
IAMJ
}

INTERNATIONAL AYURVEDIC MEDICAL JOURNAL

\section{BAHIPARIMARJANA CHIKITSA OF SHOOLA}

$\underline{\text { Nagzarkar Akshayee Ravindra }}^{1}, \underline{\text { Nagzarkar Amruta Ravindra }}^{2}, \underline{\text { Kulkarni Supriya Chinmay }}^{3}$

${ }^{1,2}$ Fourth Year B.A.M.S, ${ }^{3}$ B.A.M.S (Gold Medalist), MD (Ayurved)

Ved Ayurved Bhavan Office No.S - 16, Second Floor, Building A, Silvio Heights, Santa Inez, Panjim, Goa, India

Corresponding Author: nagzarkarakshayee@gmail.com

https://doi.org/10.46607/iamj2509052021

(Published Online: May 2021)

Open Access

(C) International Ayurvedic Medical Journal, India 2021

Article Received: 28/04/2021 - Peer Reviewed: 07/05/2021 - Accepted for Publication: 10/05/2021

Check for updates

\section{ABSTRACT}

To Study the Bahiparimarjana Chikitsa of Shoola from Bhruhatrayi and Laghutrayi. Pain is defined as an Unpleasant feeling that is conveyed to Brain by Sensory Neurons. It is an Unpleasant Sensation localised to a part of Body. It is often described in terms of Penetrating or Tissue Destructive Process of Bodily or Emotional Reaction. Pain is main reason for visiting Doctor in 50\%of cases. It is a major Symptom in many Medical Conditions and can interfere with Persons quality of Life and General Functioning. Acute Pain is usually managed with Medications such as Analgesic and Anesthetics. Caffeine, Ibuprofen, Ketamine, Opioids are some Pain killers used to treat Pain. In Modern Medicine there are few external treatments to reduce Pain like Spray, Ointment and Gels. But on contrary Ayurveda has many Bahiparimarjana Chikitsa (External Treatments) to reduce Shoola (Pain) like Ahangya (Anointing), Snehana (Oil Massage), Swedan (Sudation), etc. These External Treatments work at Site of Shoola gets absorbed at Skin by Bhrajaka Pitta and medicine reaches to each Tissue of the Body and reduces Shoola. The Popular Verse "Vatat Dhrute Nasit Ruja" means Without Vata Dosha there Cannot be Pain indicates involvement of Vata Dosha in every Pain. The Best Medicine of Vata Dosha is Sneha (Oil/Ghee/ Muscle Fat / Bone Marrow). Vata Dosha and Taila (Oil) both have Opposite Qualities. According to "Samanya Vishesha Siddhant" VataDoshahas Laghu (Light), Ruksha (Rough), Sukshma (Minute), Shita (Cold), Chala (Movable) Guna (Qualities) whereas Sneha (Taila) is Guru (Heavy), Snigdha (Unctuous), Ushna (Warm) Guna. The Sneha reduces Vata Dosha and thereby helps in reducing Shoola. This Paper will emphasize on Types of Bahiparimarjana Chikitsa of Shoola, Number of Bahiparimarjana Chikitsa mentioned for particular type of Shoola and Mode of Action of Bahiparimarjana Chikitsa. 
Keywords: Shoola, Bahiparimarjana Chikitsa, Sthanika Shoola, Vyadhijanya Shoola, Vegadharanajanya Shoola.

\section{INTRODUCTION}

Charak Samhita ${ }^{1}$ explains Two Types of Chikitsa Antaparimarjana and Bahiparimarjana Chikitsa. Susruta Samhita ${ }^{2}$ mentions Parisheka (Pouring of Medicated Liquids), Avagaha (Tub Bath),Abhangya, Shirobasti (Holding Medicated Oil on Head), Alepa (Application of Medicinal Paste), Kavalaghara (Gargling with Medicated Oil), Gandusha (Holding of Medicated Oil), etc. as Bahiparimarjana Chikitsa. Bahiparimarjana Chikitsa means the procedures done Externally on Body. Various types of Bahiparimarjana Chikitsa are mentioned in Classics. They are $A b$ hyanga, Snehana, Swedan, Lepa, Anjana (Collyrium), Tarpana (Pouring Medicated Oil in Eyes), Putapaka (Pouring Medicated Juices in Eyes), Gandusha, Kavalagraha, Pichu (cotton Swab dipped in Medicated Oil), Parisheka, Shirobasti, Karnapurana (Holding of Medicated Oil in Ears), Raktamokshana (Leech Therapy), Agnikarma (Cauterization). These External Treatment works at the Site of Shoola gets absorbed by Bhrajaka Pitta and Medicine reaches to each Tissue of Body and alleviates Shoola. The Popular Verse"Vatat dhrute nasti ruja" ${ }^{3}$ means that Without Vata Dosha there Cannot be Pain indicates the importance of Vata Dosha in Shoola. The Best Medicine for Vata Dosha is Taila (Oil). Vata Dosha and Taila both have Opposite Qualities. According to "Samanya Vishesha Siddhanta" "Vata Dosha has Laghu, Ruksha, Shukshma, Shita and Chala Guna. Taila has Guru, Snigdha, Ushna Guna. Hence Sneha reduces Vata Dosha and hereby helps in alleviating Shoola.

Here we have considered Shoola in three different categories.

1:- Sthanika Shoola (Localised Pain) includes Udara Shoola (Abdominal Pain), Shira Shoola (Headache), Akshi Shoola (Opthalmalagia), Karna Shoola (Otalgia), Danta Shoola (Toothache) etc.

2:- Vyadhijanya Shoola (Pain as Symptom in Disease) includes Shoola in Vatarakta (Gouti Atritis), Shoola in
Mutrakrucha (Pain in Dysuria), Shoola in Vrana ( Pain caused due to Wounds)etc.

3:- Vegadharanajanya Shoola (Pain caused due to Suppression of Natural Urges) includes Shoola in Purishavegadharana (Pain caused by Suppression of Urge to Defecate), Shoola in Mutravegadharana(Pain caused by Suppression of Urge to Urinate), etc.

Synonyms of Shoola:- Ruja, Vedana, Ruk, Arati, Padasuptata, Pindikodevsthana, Uruvedana, Vishleshana, Sada, Mrudita, Chatita, Avapatita, Avaunata 5

\section{Mythological Story about Origin of Shoola ${ }^{6}$ :-}

Lord Shiva once got angry on Kamadeva and he threw Trishoola (trident) on him. Watching the dreadful Trishoola (trident) approaching towards him. Kamadeva got afraid and went to hide in the body of Lord Vishnu. As Trishoola (trident) was approaching Lord Vishnu he blew on Trishoola (trident) which felt on Earth and Shoola took shelter in Panchabhautik Sharira of people and caused Shoola (Vyadhi).

Aim:- To Study the Bahiparimarjana Chikitsa of Shoola from Bhruhatrayi and Laghutrayi.

\section{Objectives:-}

1. To Study the concept of Shoola.

2. Types of Shoola.

3. Bahiparimarjana Chikitsa of Shoola.

4. Mode of action of Bahiparimarjana Chikitsa of Shoola.

5. Number of Bahiparimarjana Chikitsa's mentioned according to categories of Shoola.

Material and Methodology: -

The study of Bahiparimarjana Chikitsa of Shoola was done from Bruhatrayi's such as Charak Samhita, Sushruta Samhita, Asthang Sanghara and Asthang Hrudaya and from Laghutrayi's such as Yogaratnakar and Sharangadhara Samhita. 
References of Shoola from above mentioned Samhita's were studied.

References of Bahiparimarjana Chikitsa from Samhita's were studied.

$\downarrow$

Shoola was classified into three types.

$\downarrow$

Classification of Chitiksa of Shoola according to above mentioned Samhita's was done.

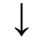

Number of Bahiparimarjana Chikitsa mentioned for a particular type of Shoola were noted.

Formulations and medicinal drugs used for Bahiparimarjana Chikitsa were also noted.

\section{OBSERVATION}

STANIKA SHOOLA

\begin{tabular}{|c|c|c|c|c|c|c|c|}
\hline SHIRA SHOOLA & C.S.Su. ${ }^{7}$ & As.H.U. ${ }^{8}$ & As.S.Su. ${ }^{9}$ & As.S.U. ${ }^{10}$ & Y.R.U. ${ }^{11}$ & Su.S.Ch. ${ }^{12}$ & Sh. S. U. ${ }^{13}$ \\
\hline Abhangya & & & & 4 & & & \\
\hline Swedan & & & & 4 & 2 & & \\
\hline Lepa & 2 & & & 7 & 10 & & \\
\hline Snehana & & & & & 2 & & \\
\hline \multicolumn{8}{|l|}{ Anjana } \\
\hline Upanaha & & & & 1 & 2 & & \\
\hline Pichu & & 1 & & & & & \\
\hline Mardana & & & & & 1 & & \\
\hline Parisheka & & & 1 & 1 & & & \\
\hline Siravedha & & & & 3 & 1 & & \\
\hline Rakta mokshana & & & & & & 1 & 1 \\
\hline Shirobasti & & & 1 & 2 & 1 & 1 & \\
\hline Agnikarma & & & & 1 & & & \\
\hline Utkarika & & & & 1 & & & \\
\hline Prakshalana & & & & 1 & & & \\
\hline
\end{tabular}

> In C.S.Su.3. explains Shirashoolahara Lepa and Shirashoolanashaka Lepa.

$>$ As.H.U.13 Drakshadi Pichu is advised.

$>$ As. S. Su.31 advises Parisheka and Shirobasti.

$>$ Sh. S. U 12 mentions Raktamokshana with Shrunga, Jalouka or Alabu.

\section{Vyadhijanaya Shoola}

\begin{tabular}{|l|l|l|l|l|}
\hline Vranaja Shoola & C.S.Ch. $^{14}$ & As.H.U. ${ }^{15}$ & Su.S.Ch. ${ }^{16}$ & Y.R.P.P \\
\hline Parisheka & 1 & 1 & 5 & \\
\hline Lepa & 2 & 1 & 4 & 6 \\
\hline Dhupana & 1 & 1 & & \\
\hline Jaloukavacharana & & 1 & & \\
\hline Swedan & & 1 & 2 & 2 \\
\hline Upanaha & 1 & 1 & 1 & \\
\hline Abhangya & & & 1 & \\
\hline Utkarika & & & 2 & 1 \\
\hline Raktamokshana & & & 3 & \\
\hline Vimlapa & & & 1 & \\
\hline
\end{tabular}


C.S.Ch.25. 2 Dhupana (Fumigation) at Vrana.

$>$ As.H.U.25. Yavadi Dhupana at Vrana.

$>$ As.H.U.26. Upanaha is advised in Sadhya Vrana (Curable Wounds).

$>$ Su.S.Ch.1. explains Parisheka with Sarpi, Taila, Dhanyamala (Fermented Gruel), Mamsa-rasa (Meat Soup), Vatahara Aushadha Siddha Kwatha (Decoction of Drugs which alleviates Vata Dosha) when it's Sheeta.

> In Pittaja Vranaja Shopha Shira, Ghruta, Madhu (Honey), Kshara Aoudaka (Alkaline Water), Ikshu rasa (Sugarcane Juice), Madhura Aushadha Siddha Shira (Milk cooked with Sweet Potency Drugs), Kwath Parisheka should be done when it's Shukhoushana (Lukewarm).

> In Kaphaja Vranaja Shopha Taila, Mutra (Urine), Kshara Aoudaka, Sura (Wine), Shukta (Vinegar), Kaphaghana Aushadhi Siddha Kwath (Decoction of Drugs which alleviates Kapha Dosha) Parisheka should be done when it's Sheeta.

Vegadharanajanya Shoola

\begin{tabular}{|c|c|c|c|c|c|}
\hline Purishavegadharanajanya Shoola & C.S .Su. ${ }^{18}$ & As.H .Su. ${ }^{19}$ & As.H.Ch. ${ }^{20}$ & As.S.Su. ${ }^{21}$ & Su.S.U. ${ }^{22}$ \\
\hline Abhangya & 1 & 1 & 1 & 1 & \\
\hline Swedan & 1 & 1 & & 1 & 1 \\
\hline Avagaha & 1 & 1 & & 1 & \\
\hline Snehana & & & & & 1 \\
\hline Phalavarti & & & & & 1 \\
\hline \multicolumn{6}{|l|}{ Mutravegadharanajanya Shoola } \\
\hline Swedan & 1 & 1 & & 1 & \\
\hline Avagaha & 1 & 1 & & 1 & \\
\hline Abhangya & 1 & 1 & & 1 & \\
\hline \multicolumn{6}{|l|}{ Apanavegadharanajanya Shoola } \\
\hline Snehana & 1 & & & & 1 \\
\hline Swedan & 1 & 1 & & 1 & 1 \\
\hline Avagaha & & 1 & & 1 & \\
\hline Abhangya & & 1 & & 1 & \\
\hline \multicolumn{6}{|l|}{ Shukravegadharanajanya Shoola } \\
\hline Abhangya & 1 & 1 & & 1 & \\
\hline Avagaha & 1 & 1 & & 1 & \\
\hline \multicolumn{6}{|l|}{ Shavathuvegadharanajanya Shoola } \\
\hline Abhangya & 1 & & & 1 & \\
\hline Swedan & 1 & 1 & & 1 & \\
\hline Snehana & & 1 & & & \\
\hline Anjana & & 1 & & & 1 \\
\hline
\end{tabular}

$>$ Abhangya, Snehana, Swedan and Avagaha with Vatahara Dravya Siddha Taila is the Best Treatment.

> For Purishavegadharanajanya Shoola Phalavarti is advised by Susruta Samhita.

> Anjana is advised by Asthang Hrudaya and Susruta Samhita in Shavathuvegadharanajanya Shoola.
$>$ Abhangya is mostly advised for different types of Vegadharanjanya Shoola.

\section{DISCUSSION}

\section{STHANIKA SHOOLA}

In Bahiparimarjana Chikitsa for Udara Shoola Lepa is advised by Charak Samhita, Sharangadhara Samhita and Yogaratnakar. In Charak Samhita Yava 
Churna and Yava Kshara should be mixed in Takra heated and applied on Udara named as Udarashoolaghana Lepa. Sharanghara Samhita advices Uadarashooladi Lepa with Madanaphala and Tikta (Katuki) should be made into Paste by adding Kanji and Water. This lukewarm Paste should be applied on Udara. Yogaratnakar mentions Tila Kalka Sweda. Tila is made into Paste this paste is tied in cloth and Potalli is made out of it. This Potalli is made warm and Swedan is done on Udara. Seka of Bilva twak, Eranda Moola twak and Tila is taken in equal parts and made into Paste with Kanji. This Paste is tied in cloth and made into Potalli and applied on Udara. Mode of action of Seka:- The Dravya used for Seka are Ushna in Guna also the Seka ia applied warm on Udara. Due to Ushna Guna Vata is reduced and Vatanolomana is achieved hence Shoola is cured.

For Shira Shoola Abhanyga and Swedana provides quick relief it is advised by Charak Samhita, Ashtang Hrudaya, Asthang Sanghara and Yogaratnakar. For Shira Shoola Charak Samhita mentions Shirashoolahara Lepa which includes drugs like Nata (Tagara Moola), Utpala, Chandana, Kustha Churna of all these drugs is taken and Ghruta is added to make Paste this Lepa is applied on Shira. Also, Shirashoolanashaka Lepa which contains Prapaundarika (White Lotus), Suradaru, Kustha, Yastimadhu, Ela, Kamala (Pink Lotus), Utpala (Blue Lotus), Agaru, Eraka, Padma kastha, Kachoraka Churna should be mixed with Ghruta to form Paste and applied on Shira. Asthang Hrudaya advices Drakshadi Pichu. Asthang Sangraha explains to tie thick Poultice made by using meat of animals of marshy region cooked with Yava, Tila, Mudga, Kulattha, Kustha, Daruharidra, Atasi and Saindhava either of these mixed with MahaSnehana should be tied warm on head. Next morning Poultice is removed, and milk boiled with Dashmoola is poured on head. Shirobasti is mentioned in Vataja Shira Shoola. Agnikarma is advised in Vataja and Kaphaja Shira Shoola. In Shira Shoola arising from Pitta and Rakta vitiation Shiravedha should be done. Also head and face should be coated and sprinkled with Satadhauta Ghruta. In Kaphaja Shira Shoola Nadi Sweda with decoction of Shigru, Nimba or Eranda is mentioned. For Krimija
Shira Shoola head and ear should be anointed with oil cooked with Devadaru, Putina, Katabhi, Sharsapa, Vidanga, Tila and Kantaka and Swedan should be done. Susruta Samhita advices Raktamokshana and Shirobasti likewise Raktamokshana is also advised by Sharangadhara Samhita. Mode of action of Lepa:- the Dravya used in Lepa are Snigdha, Ushna, Guru in Guna also Vataghna and Shoolahara. The Lepa of these dravyas when applied on Shira gets absorbed by Bhrajaka Pitta and medicine reaches to each and every tissue and reduced Shoola. Mode of action of Shirobasti:- The Taila used in Shirobasti due to its Guru, Snigdha, Ushna, Sukshma Guna reduces Vata so Shirobasti reduces Shirashoola.

In Karna Shoola Karnapurana is best treatment and it is explained by all the Acharya's. Sharangdhara Samhita explains special formulations for Karnapurana like Shyonaka Taila, Deepika Taila, Swargika Taila and SwargikaRasa. Asthang Sangraha Uttartantra explains Swedana should be done to ear and filled with oil cooked with Kustha, Rasna, Madhuka, Vamsavalekha, Shunti, Sikhi, Chandrama, Masha, Sarala and Milk. Charakacharya has advised specific Taila like Devadarvayadi Taila, Gandha Taila and Kshara. Mode of action of Karnapurna:- The Taila used in Karnapurna is Vataghna and Shoolahara when ear is filled with these Taila it quickly reduces Shoola at the same time prevents the progression ear diseases.

Akshi Shoola Anjana, Aschotana and Parisheka reliefs Shoola. Saraladi Mukhalepa, Rasanjana and Aschotana are mentioned as Tivra Shoolahara. Susruta Samhita advices if Shoola doesn't subsides by the Parisheka, Swedana, Aschotana etc then Snigdha Sweda and Raktamokshana should be done. Asthang Sangraha Uttartantra advices Aschotana. One Pala of Daruharidra is boiled in half Prastha of water and decoction is reduced to one eighth. Aschotana should be done with this decoction added with honey. Susruta Samhita explains Aschotana of Rhibera, Tagara, Manjistha, Udumbara added with Water or Milk decoction is prepared and used. Anjana made of Madhuka, Rajani, Pathya, Devadaru should be made into Paste by using Goat's Milk. For Danta Shoola Kavala, Gandusha are prominently explained also Vatidharana is advised 
which is made up of drugs like Kasisa, Shaurastri and Devadaru in equal amount with Bhavana of Water the Vati prepared should be hold in between teeth. Even it's advised to keep Hinguadi Churna on teeth by tying it in a cloth. Yogaratnakar explains Kavala and Gandusha with Vataghna Taila. Asthang Sangraha Uttartantra mentions Gandusha with Taila prepared from Hingu, Vidanga, Swarjika, Katphala, Kasisa and Kustha. Raktamokshana should be if the gums at roots are hard and painful. For Yoni Shoola Pichudharana, Parisheka and Abhanyga relieves Shoola in Yoni. Pichu dharana with Dhatakaydi Taila is advised by Charak Samhita and Pichudharana with Rasnadi Taila is advised by Asthang Sanghara.

\section{Vyadhijanaya Shoola}

For Shoola caused in Vatarakta Raktamokshana, Abhanyga, Parisheka, Lepa and Upanaha relives Shoola. It is advised by Charak Samhita, Susruta Samhita, Ashtang Hrudaya, Ashtang Sangraha and Yogaratnakar. Charak Samhita advices Raktamokshana, Parisheka with Sukosushna Dashmoola Siddha Kshira. Parisheka with Chatu Sneha. Upanaha should me tied made up of Mamsa of Aoudaka, Prasaha, Anupa animals, added with Jeevaniyagana Dravya Kalka and Ghruta, Taila, Vasa, Majja. VataraktaShoolanashaka Lepa is advised in Charak Samhita made by using drugs like Rasna, Guduchi, Madhuka, Bala, Nagabala, Jeevaka, Rushabhaka paste should be made by adding Milk. This Paste should be cooked in Ghruta. Once Ghruta is prepared it should be again cooked with Madhuchistha and used in Shoola caused by Vatarakta. Abhanyga with Madhuyasthi Taila is advised in Asthang Sanghara.

Mode of action of Raktamokshana:- Due to vitiated Vata and Rakta there is severe Shoola by Raktamokshana vitiated Rakta and Vata is thrown out hence helps in reducing Shoola.

In Vranaja Shoola Parisheka, Upanaha and Raktamokshana are helpful. Yavadi Dhupana at Vrana site is also advised by Ashtang Hrudaya. Susruta Samhita advices Parisheka by Ghruta, Taila, Dhanyaamla, Mamsarasa, Vatahara Aushadhi Kwath. In cases of Pitta dominant Vrana Parishek with Milk, Ghruta, Madhu, Sugar Syrup, Sugarcane juice, Madhura Aushadhi Kwath and Kwath of Kshiri Vruksha. In case of Kapha dominant Vrana Parisheka by Taila, Mutra, Kshraoudaka, Sura, Sukta, Kaphaghna Aushadhi Siddha Kwatha. Dhupana with Agaru etc redues Shoola. Mode of action of Parisheka:- Parisheka is pouring a medicated Kwatha, Milk, Buttermilk, Ghruta, Taila, etc on a particular part of body or on Vrana. It reduces Sthanika Vata Dosha joins the fractured bone, cleanses dirty, infected, punctured, non-healing wounds. It reduces Shoola from Vrana by Laghu, Snigdha, Krimighna, Shoolaghna and Ushana qualities.

For Shoola in Gulma Snehana, Swedana and Parisheka are prominently used whereas Acharya Susruta advices Phalavarti and Yogaratnakar advices Raktamokshana. Yogaratnakar advices Swedana of Vataghna Dravya and Pinda Sweda. Charak Samhita advices Nadi, Prasthara and Sankara Sweda. Mode of action of Swedan:- Vitiated Vata due to its Ruksha Guna absorbs Snighata and cause Stambhan. Swedan is Snigdha and Ushna so relives Stambha. Ushna Guna of Swedan does Sroto Suddhi and Ama Pachana, Vatanolomana and reduces Shoola. It also relives Gauravata in body it causes excretion of watery content through Sweda so lightness is achieved. Snehana, Swedan and Abhanyga is mostly used for Vatavyadhijanya Shoola. Narayan Taila is advised for Abhanyga by Sharangadhara Samhita. In Ghrudhrasijanya Shoola Agnikarma and Shiravedha is explained. Sharangadhara Samhita explains Ghrudhrasyadishu Lepa. In Bhagandarajanya Shoola Swedan and Parisheka is advised by Susruta Samhita whereas Asthang Hrudaya explains Snigdha Pinda Sweda whereas Yogaratnakar advices Raktamokshana and Agnikarma.

\section{Vegadharanajanya Shoola}

In Vegadharanajanya Shoola all Vataghana treatments should be given like Abhanyga, Swedan and Avagaha. For Purishavegadharanajanya Shoola Phalavarti is advised by Susruta Samhita. For Shavathuvegadharanajanya Shoola Anjana is advised by Asthang Hrudaya and Susruta Samhita. Mode of action of $\boldsymbol{A b}$ hangya:- When Abhangya is done for sufficient time Taila reaches to different Dhatus, the drugs used in Taila is absorbed into Skin. Abhangya chiefly Snigdha and Guru Guna acts as Vatahara, Balya, Snehana and Pushtikara. Mrudu Guna reduces Stambha by its 
opposite qualities. Sukshma Guna helps to penetration of drugs into minute channels. Sneha used for Avagaha enters the Body through Sira Mukha, Roma Kupa and Dhamani nourishes the body and thus provides relief.

Avagaha sweda is more beneficial as its action is directly on the Pakavashaya.

This Literary Research provides a scope to study further topics in future like:

1. To Study Udara Shoola and its Bahiparimarjana Chikitsa in Classics.

2. To Study Snehana, Swedana as Bahiparimarjana Chikitsa in different Vyadhis.

3. To Study effects of different types of Swedan in Shoola.

\section{CONCLUSION}

The Study highlights the importance of Bahiparimarjana Chikitsa of Shoola mentioned in Classics. We can Conclude that Seka is effective in Udara Shoola. Lepa and Shirobasti helps in alleviating Shira Shoola. In Karna Shoola Karnapurana is beneficial. Aschotana and Anjana are useful in Akshi Shoola. Raktamokshana is Best to relieve severe Shoola in Vatarakta. For Vranaja Shoola Parishek is beneficial. Swedan is effective for Shoola caused due to Gulma. Abhangya helps in alleviating all Types of Vegadharanjanya Shoola.

\section{REFERENCES}

1. Prof. Vd. Ya. Go. Joshi, Charak Samhita of Sri. Chakrapanidattta Virachita Ayurved Deepikavyakhaya, Marathi Translation with Yashwant Teeka, Aragvadhiya Adhaya, Vaidya Mitra Prakashan, Pune, 11 Feb 2008, Comp. Print Kalpana Pune, $3^{\text {rd }}$ Edition, Sootrasthan, 3:2, Charakapanidatta Ayurveda Deepika Teeka, Pg. No: 57,58 .

2. Vd. Jadavji Trikamji Acharya, Susruta Samhita of Susruta with Nibandhsangraha Commentry of Sri Dalhanacharya, Vedothpatti Adhaya, Chaukhambha Surabharati Prakashan, Varanasi, 2017, A. K. Lithographers Delhi, Sootrasthan 1:27 Sri Dalhanacharya Nibandhasangraha Teeka, Pg.No: 7.

3. Vd. Jadavji Trikamji Acharya,Susruta Samhita of Susruta with Nibandhsangraha Commentry of Sri Dalhanacharya, Amapakvaishaniya Adhaya, Chaukhambha Surabharati Prakashan, Varanasi, 2017, A.K. Lithographers Delhi, Sootrasthan 17:7, Pg.No: 83.
4. Dr. Anna Moreswar Kunthe and Krsna Ramchandra Sastri Narve, Asthang Hrudaya of Vagbhata with Commentries Sarvangasundara of Arunadatta and Ayurvedarasayana of Hemadri, Ayushkamiya Adhaya, Chaukhambha Sanskrit Sansthan, Varanasi, 2018, Globe Offset Press New Delhi, Reprinted 2018, Sootrasthan 1:14, Pg.No: 10.

5. Prof. Vd. Ya. Go. Joshi, Charak Samhita of Sri. Chakrapanidattta Virachita Ayurved Deepikavyakhaya, Marathi Translation with Yashwant Teeka, Jwara Nidana, Vaidya Mitra Prakashan, Pune, 11 Feb 2008, Comp. Print Kalpana Pune, $3^{\text {rd }}$ Edition, Nidansthana, 1:21, Pg.No: 436, 437.

6. Vd. Laksmipati Sastri, Yogaratnakar with Vidyotini Hindi Commentry, Shoola Nidana, Chaukhambha Prakashan, Varanasi, Edition: Reprinted 2018, Uttaradha, Shoola Nidana : 1,2, Pg No : 1 .

7. Prof. Vd. Ya. Go. Joshi, Charak Samhita of Sri. Chakrapanidatta Virachita Ayurved Deepikavyakhaya, Marathi Translation with Yashwant Teeka, Aragvadhiya Adhaya,Vaidya Mitra Prakashan, Pune, 11 Feb 2008, Comp. Print Kalpana Pune, $3^{\text {rd }}$ Edition, Sootrasthan, 3:23,24, Pg.No: 61,62.

8. Dr. Anna Moreswar Kunthe and Krsna Ramchandra Sastri Narve, Asthang Hruduya of Vagbhata with Commentries Sarvangasundara of Arunadatta and Ayurvedrasayana of Hemadri, Timira Pratishedha, Chaukhambha Sanskrit Sansthan, Varanasi, Globe Offset Press New Delhi, Edition: Reprinted 2018, Uttarsthana, 13: 5,6, Pg.No: 819.

9. Prof. K.R. Srikantha Murthy, Asthang Sanghara of Vagbhata, English Translation, Vol. 1, Gandusadi Vidhi Adhaya, Chaukhambha Orientalia, Charu Printers Varanasi, First Edition: 1995, Sootrasthan, 31:18, Pg.No: 538.

10. Prof. K. R. Srikantha Murthy, Asthang Sanghara of Vagbhata, English Translation, Vol. 3 , Siro Roga Pratisedha, Chaukhambha Orientalia, Charu Printers Varanasi, First Edition: 1997, Uttarsthan, 28:3,5,6,7,8,9,10,11,13,14,15,20,27,33, Pg.No: $244,245,246,247,248,249,250$.

11. Vd. Laksmipati Sastri, Yogaratnakar with Vidyotini Hindi Commentry, Shiroroganam Chikitsa, Chaukhambha Prakashan, Varanasi, Edition: Reprinted 2018, Uttaradha, Vataja Chikitsa: 1,2,4,5, Shirobasti Vidhi: 1,2,3, Shlemaja Chikitsa: 2, SuryavartaArdhavabhedaka Chikitsa:4,5,6,8,10, AnnatavataShankhaka Chikitsa: 1,3,4,5, Pg. No: 333,334,335,337,338. 
12. Vd. Jadavji Trikamji Acharya, Susruta Samhita of Susruta with Nibandhsangraha Commentry of Sri Dalhanacharya, Vatavyadhi Chikitsa, Chaukhambha Surabharati Prakashan, Varanasi, 2017, A.K. Lithographers Delhi, Chikitsasthan, 4:19, Pg.No: 422.

13. Pandit Parasurama Sastri, Vidyasagar, Sarangadhara Samhita by Pandit Sarangadharacharya with Commentaries Adhamalla's Dipika and Kasirama's Gudhartha Dipika, Shonitasrava Vidhi, Chaukhambha Publication New Delhi, Globe Offset Press New Delhi, Edition: Reprinted 2013, Uttarakhand, 12:17, Pg. No: 375.

14. Dr. Brahmanand Tripathi, Charak Samhita of Agnivesa, Vol. 2, Dvivrananija Chikitsa, Chaukhambha Surabharati Prakashan Varanasi, A. K. Lithographers Delhi, Edition: 2020, Chikitsasthan, 25: 77,78,79,109,111, Pg. No: $852,853,859,860$.

15. Dr. Anna Moreswar Kunthe and Krsna Ramchandra Sastri Narve, Asthang Hruduya of Vagbhata with Commentries Sarvangasundara of Arunadatta and Ayurvedrasayana of Hemadri, Vrana Pratisedha, Sadhyovrana Pratisedha, Chaukhamba Sanskrit Sansthan, Varanasi, Globe Offset Press New Delhi, Reprinted 2018, Uttarsthana, 25/25,26, Pg.No: 866, 26/11,12, Pg.No: 870.

16. Vd. Jadavji Trikamji Acharya, Susruta Samhita of Susruta with Nibandhsangraha Commentry of Sri Dalhanacharya, Dvivranya Chikitsa,Sadhyovrana Chikitsa, Chaukhambha Surabharati Prakashan, Varanasi, 2017, A. K. Lithographers Delhi, Chikitsha sthan 1/14-29, Pg.No:398,399,2/24,25, Pg.No: 409.

17. Vd. Lakshmipati Sastri, Yogaratnakar with Vidyotini Hindi Commentry, VranaShotha Chikitsa, Chaukhamba Prakashan, Varanasi, Edition: Reprinted 2018, Uttaradha, Raktamokshana: 1,2,3, Lepa: 1,2,9, Upanaha: 1,2, Pg.No: 173,174.

18. Prof. Vd. Ya. Go. Joshi, Charak Samhita of Sri. Chakrapanidatta Virachita Ayurved Deepikavyakhaya, Marathi Translation with Yashwant Teeka, Navegadharaniya Adhaya, Vaidya Mitra Prakshana Pune, 11 Feb 2008, Comp. Print Kalpana Pune, $3^{\text {rd }}$ Edition, Sootrasthan, 7: 7,9,11,13,17, Pg.No: 108.

19. Dr. Anna Moreswar Kunthe and Krsna Ramchandra Sastri Narve, Asthang Hruduya of Vagbhata with Commentries Sarvangasundara of Arunadatta and Ayurvedrasayana of Hemadri, Roganutpadaniya Adhaya, Chaukhamba Sanskrit Sansthan, Varanasi, Globe Offset Press New Delhi, Reprinted 2018, Sootrasthan, 4: 5,9,20, Pg. No: 53,54, 56.

20. Dr. Anna Moreswar Kunthe and Krsna Ramchandra Sastri Narve, Asthang Hruduya of Vagbhata with
Commentries Sarvangasundara of Arunadatta and Ayurvedrasayana of Hemadri, Atisara Chikitsa, Chaukhamba Sanskrit Sansthan Varanasi, Globe Offset Press New Delhi,Reprinted 2018, Chikitsasthan, 9:45, Pg. No: 659.

21. Prof. R.K. Srikantha Murthy, Asthang Sanghara of Vagbhata, English Translation, Vol.1, Roganutpadaniya Adhaya, Chaumukha Orientalia Varanasi, Charu Printers Varanasi, First Edition: 1995, Sootrasthan, 5: 6,10,11, 21, Pg.No: 72,73,75.

22. Vd. Jadavji Trikamji Acharya, Susruta Samhita of Susruta with Nibandhsangraha Commentry of Sri Dalhanacharya, Udavarta Pratishedha Adhaya, Chaumukha Surabharati Prakashan, Varanasi, 2017, A.K. Lithographers Delhi, Uttartantra, 55: 20, Sri. Dalhanacharya Nibandhsangraha Teeka 201/2, Pg.No: 778 .

\section{Source of Support: Nil Conflict of Interest: None Declared}

How to cite this URL: Nagzarkar Akshayee Ravindra et al: Bahiparimarjana Chikitsa Of Shoola. International Ayurvedic Medical Journal \{online\} 2021 \{cited May, 2021\} Available from:

http://www.iamj.in/posts/images/upload/1093_1100.pdf 